\title{
ОЦІНКА ЯКОСТІ ЖИТТЯ, ПОВ'ЯЗАНОЇ ІЗ ЗДОРОВ’ЯМ У МЕДИЦИНІ
}

\section{Оцінка якості життя, пов'язаної із здоров'ям у медицині}

\section{П. О. Герасимчук, Д. Б. Фіра, А. В. Павлишин}

Тернопільський національний медичний університет імені І. Я. Горбачевського мОЗ України

Вступ. За останні десятиліття в медичній практиці все більшу увагу приділяють оцінці «якості життя, пов'язаної зі здоров'ям» («health-related quality of life» HRQOL). Аналіз показників якості життя дозволяє оцінити не тільки здоров'я та благополуччя населення, а і якість надання медичної допомоги та реабілітації хворих, їх ефрективність та стан медицини в цілому.

Мета дослідження - вивчити та проаналізувати вітчизняні та зарубіжні літературні джерела щодо сучасних методів оцінки якості життя пацієнтів у медицині в контексті розвитку науки.

Матеріали і методи. Пошук літератури, що знаходиться у вільному доступі в друкованих виданнях, проводили в електронних бібліотеках та інформаційних ресурсах мережі «lнтернет», PubMed, Medline. 3238 знайдених тематичних статей, в огляд літератури включено 76 наукових публікацій. Отримані дані обробили та синтезували усі автори.

Результати. Проведено огляд даних сучасної наукової медичної літератури з вивчення якості життя в медицині при окремих нозологічних формах захворювань. Найбільш раціональним методом оцінки якості життя на сучасному етапі вважається застовування в дослідженні стандартизованих опитувальників, що є необхідним для отримання результатів, які можуть бути порівняні між собою, незалежно від країни дослідження. На даний час відома значна кількість спеціальних опитувальників для таких нозологій, як цукровий діабет, бронхіальна астма, рак, судинна патологія тощо. Однак значна їх частка знаходиться в стадії розробки та адаптації для різних країн світу. Процес культурної адаптації опитувальників є надзвичайно складним і потребує тісної взаємодії міжнародних розробників, перкладачів, психологів з метою їх використання в різних етнічних та культурно-соціальних групах населення.

Висновки. Проведений огляд літературних джерел дозволяє зробити висновок, що поняття «якість життя, пов'язана зі здоров'ям» (HRQOL) та його вивчення $\epsilon$ новою сучасною методологією охорони здоров'я. Вона дозволяє оцінити результати лікування хворих, реабілітаційні програми та медико-соціальну адаптацію пацієнтів, доповнюючи традиційні методики як на індивідуальному, так і на груповому рівнях.

\section{Assessment of quality of life related with health in the medicine}

P. O. Gerasymchuk, D. B. Fira, A.V. Pavlyshyn

I. Horbachevsky Ternopil National Medical University

e-mail: firadb@tdmu.edu.ua

Summary. In recent decades, more and more attention has been paid in health practice to the assessment of "healthrelated quality of life" (HRQOL). The analysis of quality of life indicators allows us to assess not only the health and well-being of the population, but also the quality of medical care and rehabilitation of patients, their effectiveness, and the state of medicine in general.

The aim of the study - to learn and analyze domestic and foreign literature sources on modern methods of assessing the quality of life of patients in medicine in the context of science.

Materials and Methods. The search for literature that is freely available in printed publications was conducted in electronic libraries and information resources of the Internet, PubMed, Medline. From the 238 thematic articles found, 76 scientific publications were included in the literature review.

Results. A review of data from the modern scientific medical literature on the study of quality of life in medicine for certain nosological forms of disease has been conducted. The most rational method of assessing the quality of life at the present stage is the use of standardized questionnaires in the study, which is necessary to obtain results that can be compared with each other, regardless of the country of research. Currently, a significant number of special descriptions are known. for nosologies such as diabetes, bronchial asthma, cancer, vascular pathology, etc. However, a significant part of them is under development and adaptations for different countries of the world. The process of cultural adaptation of questionnaires is extremely complex and requires close cooperation of international developers, translators, psychologists in order to use them in different ethnic and cultural and social groups.

Conclusions. Thus, a review of the literature suggests that the concept of "quality of life associated with health" (HRQOL) and its study is a new modern methodology of health care. It allows to evaluate the results of patients' treatment, rehabilitation programs and medical and social adaptation of patients, complementing traditional methods, both at the individual and group levels. 
Ключові слова: якість життя; якість життя, пов'язана із здоров'ям; HRQOL.

\section{ВСТУП}

Одним із важливих напрямків у розвитку сучасної медицини є дослідження якості життя (ЯЖ) хворих, яке зайняло відповідне місце в медичній галузі, та продовжує прогресивно розвиватися. За останній час вивчення ЯЖ стало окремим напрямком досліджень, оскільки кінцевою метою лікування будьякої патології необхідно вважати досягнення кращого результату зі збереженням працездатності, хорошого самопочуття та адаптації пацієнта в суспільстві. Без нього неможливо зробити висновки про кінцеві результати лікування [1, 2].

Це зумовлене тим, що лише клінічні критерії далеко не завжди відповідають соціальній значущості отриманих результатів, а також суб'єктивній оцінці самого хворого. Адже медичні проблеми не можуть існувати ізольовано від побутових і соціальних умов. Тому глобальним завданням медицини $€$ не тільки вилікувати хворобу, а й створити всі умови для максимально повного відновлення працездатності пацієнта та забезпечити його соціальну адаптацію.

Якість життя - в широкому розумінні являє собою міждисциплінарне поняття, яке входить у сореру інтересів психології, економіки, соціології, медицини й охорони здоров'я. Зараз виділяють понад 100 визначень ЯЖ як глобальних, 3 акцентом на щастя і задоволення або пов'язаних зі здоров'ям, так і структурних, які пов'язані з визначенням Яж через його компоненти або домени [3, 4].

Галузі використання дослідження ЯЖ в практиці охорони здоров'я досить різносторонні. Сюди відносять: стандартизацію методів лікування, індивідуальний моніторинг стану хворого 3 оцінкою ранніх та віддалених результатів лікування, популяційні дослідження з виділенням груп ризику, часу розвитку ризиків, фракторів і територій ризиків, оцінку ефективності профрілактичних програм, експертизу нових лікарських препаратів тощо. Це зумовлює необхідність подальшого розвитку, оптимізації, стандартизації та валідації методів дослідження ЯЖ, що дозволить значно покращити результати лікування хворих із розробкою універсальних алгоритмів.

Метою дослідження було вивчити та проаналізувати вітчизняні та зарубіжні літературні джерела щодо сучасних методів оцінки якості життя пацієнтів у медицині в контексті розвитку науки.

\section{МАТЕРІАЛИ I МЕТОДИ}

Пошук літератури, що знаходиться у вільному доступі в друкованих виданнях, проводили в елек-
Key words: quality of life; quality of life related with health; HRQOL.

тронних бібліотеках та інорормаційних ресурсах мережі «Інтернет», PubMed, Medline. 3238 знайдених тематичних статей, в огляд літератури включено 76 наукових публікацій. Отримані дані обробили та синтезували усі автори.

\section{РЕЗУЛЬТАТИ Й ОБГОВОРЕННЯ}

Проблема дослідження якості життя в медицині набула своєї актуальності в другій половині XX ст., коли стало зрозумілим, що при лікуванні хворих важливо не тільки побороти хворобу, але і створити відповідні умови для покращення якості їх життя та соціального фрункціонування [1, 4]. В основу досліджень було покладено фрізичні, психологічні, емоційні, соціальні, культурні, повсякденні складові якості життя. Спектр досліджень у подальшому розширювався, що було зумовлено відповідними положеннями життя в суспільстві у контексті його культури, системи цінностей та економічно-соціального розвитку, які значною мірою визначають медико-соціальну адаптацію хворого в суспільстві та визначають його ЯЖ [5-8].

На сьогодні існує значна кількість визначень якості життя і кожне з них доповнює та конкретизує трактування терміну, однак загальноприйнятого визначення даного поняття немає і досі [9-12].

У 1982 p. R. M. Kaplan и Bush запропонували термін «якість життя, пов'язана зі здоров'ям» («health-related quality of life» - HRQOL), на ґрунті якого в 1984 р. ВОО3 фрормулює принципово нове визначення здоров'я як «стан фрізичного, психічного та соціального благополуччя, а не тільки відсутність хвороб» [13-15]. Під ним розуміють ступінь благополуччя та задоволення тими сторонами життя, на які впливає хвороба та їі лікування, з точки зору суб'єктивного сприйняття самого пацієнта. Також якість життя визначають як показник адаптації хворого до наявності у нього хвороби, можливість виконання звичайних функцій, пов'язаних із соціально-економічним положенням пацієнта на роботі й у побуті. Такі підходи дозволяють зробити глибокий і багатокомпонентний аналіз фрізичних, фрізіологічних, психологічних, емоційних і соціальних проблем хворої людини [16-23].

Єдиних, загальноприйнятих критеріїв і норм ЯЖ не існує. Їх варіабельність зумовлена різними критеріями (вік, стать, національність хворого, характер його трудової діяльності, культурний розвиток, стан суспільства тощо), що зумовлює суб'єктивність отриманих показників [24].

Тому для визначення ЯЖ необхідно використовувати такий інструмент, який би охоплював максимальну кількість дослідних показників, з можли- 
вістю їх аналізу, та був зіставимий 3 іншими показниками здоров'я пацієнта. Результатом такої роботи став Міжнародний консенсус із стандартизованого дослідження ЯЖ [1, 2, 25].

Методологія дослідження якості життя ґрунтується на загальних принципах, які викладені в протоколі Міжнародного проекту оцінки якості життя - International Quality of Life Assessment (IQOLA) Project. Вона $€$ багатокомпонентною і складається з декількох етапів: розробки протоколу дослідження, вибору інструменту (інструментів) дослідження, обстеження і лікування хворих, збору даних, фрормування баз даних, статистичної обробки результатів з їх аналізом та інтерпритуванням [26, 27].

Для оптимізації процесу дослідження ЯЖ в різних країнах світу створені та фрункціонують інститути, центри, асоціації, спільноти 3 дослідження HRQOL, розробляються інструменти дослідження і бази даних, проводиться їх адаптація для широкого використання, випускаються науково-практичні журнали, присвячені даній проблемі. Все це дозволяє оцінити не тільки здоров'я та благополуччя населення, а і якість надання медичної допомоги та реабілітації хворих, їх ефективність та стан медицини в цілому [28-31]

На основі кропіткої роботи дослідників усього світу за останні десятиліття створені й фрункціонують численні бази даних з дослідження якості життя в різних напрямках медицини, а саме:

- Статистика ВОО3: база даних Глобальної обсерваторії охорони здоров'я (сайт ВОО3 http:// www.who.int);

- EurLIFE (Європейська обсерваторія якості життя) (http://www.eurofound.europa.eu/areas/ qualityoflife/eurlife/index.php);

- World Happiness Database (Всесвітня база даних щастя) (http://www1.eur.nl/fsw/happiness/);

- Patient-reported outcome and Quality of life instruments database (ProQolid) - База даних 3 інструментів оцінки пацієнтом результатів лікування і якості життя (http://www.proqolid.org/);

- Medical outcome trust «Довіра медичним результатам» (http://www.outcomestrust.org/);

- Statistics Solutions (Статистичні рішення) (http://www.statisticssolutions.com/resources/ directoryof-survey instruments);

- RAND Health (Корпорація RAND), RAND Health Care (http://www.rand.org/health/ http://www. rand.org/health-care) та ін.

Бази дозволяють проводити порівняльне дослідження показників ЯЖ у всьому світі, з аналізом і стандартизацією отриманих результатів, для їх подальшого використання у світовій медицині [32-35].

Вивчення HRQOL дає змогу визначити фактори, які дозволяють покращити ЯЖ хворого, та зна- йти ним сенс життя 3 відповідною соціальною адаптацією в суспільстві. Однак необхідно розуміти, що показники HRQOL $€$ динамічними, і в ході розвитку суспільства відношення до них будуть змінюватися. Кожне наступне покоління буде розробляти свої критерії ЯЖ, що буде спонукати до зміни визначення його критеріїв та їх адекватній корекції з урахуванням змін у медичній галузі та соціальному розвитку суспільства.

Кінцевою метою будь-якої системи охорони здоров'я варто вважати досягнення максимальних показників ЯЖ хворого на етапах надання медичної допомоги, зі збереженням працездатності та його хорошого стану і самопочуття [33, 34, 36, 37].

На сьогодні для оцінки ЯЖ запропоновано близько 1200 різних інструментів. Для прикладу, лише база даних Pro Qolid містить їх понад 700, з описанням використання [38]. 3 них $22 \%$ відносяться до загальних методик, 18 \% оцінюють окремі виміри чи домени, біля 46 \% є специфічними для якоїсь хвороби чи групи людей, 10 \% пов'язані з економічною оцінкою корисності, 1\% - індивідуалізовані методики і техніки. В загальному 15 можливих критеріїв оцінки ЯЖ торетично дає змогу створити понад 200000 принципово різних вимірювальних систем [39].

Найбільш раціональним методом оцінки ЯЖ на сучасному етапі вважається застовування в дослідженні стандартизованих опитувальників, що $€$ необхідним для отримання результатів, які можуть бути порівняні між собою, незалежно від країни дослідження [40].

За рекомендацією ВОО3, в оцінку HRQOL включені наступні критерії, які лежать в основі фрормування різних анкет та опитувальників:

1. Фізичні - життєва активність, енергія, втомлюваність, біль, дискомфорт, сон, відпочинок;

2. Психологічні - позитивні й негативні емоції, пізнавальні фрункції, самооцінка, рухливість, зовнішній вигляд;

3. Клінічні характеристики захворювання скарги, об'єктивні, суб'єктивні ознаки захворювання, наявність ускладнень;

4. Рівень незалежності - працездатність, щоденна активність, залежність від ліків і лікування;

5. Суспільне життя - особисті взаємовідносии, суспільна адаптація, сексуальна активність;

6. Навколишнє середовище - побут, безпека, загальне благополучя, доступність і якість медичної та соціальної допомоги, екологія, доступність інфрормації, можливість навчання;

7. Духовність - релігія, особисті погляди, поведінкові реакції.

Формування з цих критеріїв відповідних доменів та питань дозволяє створити опитувальники, які дають змогу об'єктивно оцінити якість життя.

У клінічній практиці показники ЯЖ використовуються в наступних основних напрямках: 
- для оцінки ефрективності лікування з використанням динаміки показників ЯЖ на різних етапах лікування (ранніх і віддалених результатів лікування);

- для оцінки стану хворого у міру змін клінічної картини хвороби; ЯЖ має визначальне значення при виборі стратегії лікування інкурабельного хворого;

- ЯЖ хворого використовується як додатковий критерій при підборі індивідуальної терапії, клінічної оцінки конкретного лікувального препарату або хірургічного (терапевтичного) методу лікування, фрізичної реабілітації інвалідів;

- зміни показників ЯЖ хворих дозволяють оцінити фрізіотерапевтичне, паліативне, оздоровчі методи лікування і роботи медичного персоналу, готовність пацієнтів до участі в профілактичних заходах;

- оцінюється економічна ефективність терапевтичного, хірургічного або відновного лікування;

- дані про ЯЖ хворих можуть бути корисні для оцінки якості роботи лікувального відділу чи лікувального закладу в цілому, оцінки роботи органів охорони здоров'я, покращення системи охорони здоров'я;

- показники ЯЖ найбільшою мірою дозволяють отримати цілісну уяву про самопочутя хворого очима пацієнта, особливо по відношенню до пацієнтів із хронічними та загрозливими для життя захворюваннями [1, 2, 40, 41].

Оцінку HRQOL проводять на основі відповідей хворих на стандартні питання, які лежать в основі сучасних опитувальників. Єдиних критеріїв і стандартів для HRQOL не існує. Кожний опитувальник має свої особливості та шкалу оцінювання, які адаптуються до конкретних регіонів з визначенням відповідної умовної норми. Це дозволяє в подальшому проводити їх порівняльну оцінку з показниками хворого, та робити висновки щодо якості його життя [42-45].

Інтегральна інформація про фрізичне, психологічне, духовне та соціальне фрункціонування дозволяє отримати відомості про загальні закономірності реакціїі хворого на патологічний процес, встановити індивідуальні особливості його реакції на захворювання, оцінити ефективність проведеного лікування, та використати ці дані для корекції схеми лікування та подальшої реабілітації. При цьому популяційні показники ЯЖ мають велике значення для клінічної практики, оскільки з ними проводиться порівняння отриманих даних. Наявність популяційних норм дозволяє визначити яким чином конкретне захворювання впливає на ЯЖ пацієнта в різних вікових і соціальних групах, як змінюються показники профрілю ЯЖ відносно норми залежно від виду патології та комплексу проведених лікувально-реабілітаційних заходів [1, 2]. Дані про ЯЖ лежать в основі побудови реабілітаційних програм як середників медичної і соціальної адаптації хворого. Створюючи ці програми, органи влади і суспільні організації можуть опиратися на цінну інфрормацію про ЯЖ обстежених груп хворих в різних регіонах, адаптуючи їх до відповідних умов проживання. Не можна вважати ефективною ту програму (лікувальну, реабілітаційну, соціальну та ін.), яка не приводить до покращення ЯЖ хворого, або призводить до його суттєвого погіршення, не створюючи таким чином максимальних умов для медико-соціальної адаптації пацієнта.

Існує досить значна кількість опитувальників за оцінкою HRQOL (понад 4000), які можна розділити на наступні групи: універсальні (загальні) для дітей та дорослих і спеціальні (за галузями медицини, нозологічними фрормами окремих захворювань, методами лікування, окремим станом хворого). За структурою опитувальники діляться на профрільні (включають декілька шкал, які описують різні параметри якості життя, або оцінюють кожний компонент якості життя окремо) та індекси (містить єдине циорове значення). Для оцінки стану ЯЖ дані, отриманні в опитувальнику, відповідним чином перераховуються в окремі числові значення (бали), які дозволяють провести їх статистичну обробку $[1,33,34,45,46]$.

Загальні опитувальники використовуються для оцінки якості життя як здорових людей, так і для широкого кола хвороб і категорій хворих. Вони можуть використовуватися в популяційних дослідженнях з метою розробки нормативів та встановлення різних змін якості життя у різноманітних хворих (індивідуально або в групах), а також для оцінки ефрективності різних програм охорони здоров'я в цілому.

Перевага загальних опитувальників полягає в тому, що вони дозволяють проводити порівняльну оцінку впливу різних медичних програм на ефективність HRQOL як у окремих хворих, так і в популяції у цілому.

Спеціальні опитувальники навпаки використовуються для оцінки якості життя пацієнтів 3 конкретними захворюваннями, або хворих окремих груп населення (наприклад дітей). Вони дозволяють встановити зміни HRQOL у хворих, які виникли за досить короткий проміжок часу для оцінки еорективності конкретного методу лікування. Спеціальні опитувальники є більш чутливими для конкретного захворювання, оскільки містять специорічні компоненти, характерні для його перебігу та лікування. Вони дозволяють оцінити якусь одну складову HRQOL (фізичний чи психічний стан), або оцінити HRQOL при конкретному захворюванні, чи еорективність окремого методу лікування.

Спеціальні опитувальники володіють високою чутливістю, але їх використання обмежується вузькою конкретною сфрерою використання. Най- 
більшого поширення серед спеціальних опитувальників набули «Gastrointestinal Symptom Rating Scale», «Arthritis Impact Measurement Scale», «Functional Assessment of Multiple Sclerosis», «Oral Health Quality of Life» та ін.

Кількість опитувальників, які використовуються при оцінці HRQOL хворого, може коливатися в різних межах, залежно від мети дослідження, включаючи в себе поєднання як загальних, так і спеціальних опитувальників. Вибираючи опитувальники для дослідження, необхідно пам'ятати, що вони повинні відповідати меті та завданням дослідження, охоплювати всі параметри здоров'я, бути стандартизованими, універсальними, надійними, чутливими, простими у використанні, та давати можливість кількісної оцінки параметрів здоров'я. Опитувальники чутливі для оцінки ЯЖ в одних випадках, можуть бути нечутливими для інших [45-47].

Більшість опитувальників доступна для самостійного заповнення хворим, за допомогою опитування лікарем при бесіді з хворим, по телефону, з використанням електронних ресурсів мережі «Internet», а також передбачають заповнення родичами або опікунами хворого. Останні методики отримали назву прокси-версії і використовуються за умови неможливості самостійного заповнення хворим, наприклад при психічних захворюваннях або тяжкому стані пацієнта [48, 49].

Кожний опитувальник складається 3 трьох основних частин, які включають в себе домени (характеризують показники або аспекти життя), питання (використовуються для визначення конкретної інформації про стан здоров'я), рівні (варіанти відповідей на питання, залежно від тяжкості проявів показників здоров'я). Комбінування доменів, питань та рівнів, з отриманням відповідних числових значень, індексів та їх вагових коефіцієнтів, дозволяє оцінити стан здоров'я хворого, залежно від призначення опитувальника. Однак варто враховувати той фракт, що ці показники є відмінними для різних країн. Це потребує проведення валідизації опитувальників для кожної країни або використання в розрахунках вагових коефіцієнтів для перетворення кожного профрілю якості життя в одне підсумкове значення, яке порівнюється 3 індексом корисності з відповідного набору значень, які розроблені для різних країн. Ці набори стають доступними на офріційних сайтах опитувальників після проведення реєстрації дослідження [50-54].

Процес культурної адаптації опитувальників $€$ надзвичайно складним і потребує тісної взаємодії міжнародних розробників, перкладачів, психологів з метою їх використання в різних етнічних та культурно-соціальних групах населення.

На сьогодні в Україні $€$ значна кількість опитувальників у повних і скорочених версіях, які пройшли культурну адаптацію, що дозволяє викорис- товувати їх в медичній практиці в нашій державі: «MOS SF-36», («The Medical Outcomes Study 36-Item Short-Form Health Survey»), «European Quality of Life», «EQ-5D»), «SIP» («Sickness Impact Profile»), «NHP» («Nottingham Health Profile»), «McMaster Health Index Question Naire», «Psychological General Well Being Index», «General Health Rating Index», «Quality of Well Being Scale» та інші [1-3, 55-57].

Використовуючи ці опитувальники, варто пам'ятати, що вони характеризують лише як паці$€$ єт переносить своє захворювання, вони не враховують думки членів сім'ї та медичних працівників, та висновки робляться на основі їх багатокомпонентної структури. Завдання дослідника полягає в аналізі усіх критеріїв, які лежать в основі оцінки HRQOL, з відповідною адаптацією показників відносно завдання та мети дослідження.

Популяційні дослідження дозволяють провести оцінку різних прошарків суспільства, категорій населення (професійних, міських або сільських жителів), жителів які хворіють конкретною патологією, і суспільства (популяції) в цілому. Під популяційною нормою ЯЖ розуміють значення показників ЯЖ населення тієї чи іншої країни, того чи іншого регіону [58].

Дослідження ЯЖ на популяційному рівні дозволяє розробляти популяційні норми, які, у свою чергу, можуть бути використані:

- при порівнянні показників ЯЖ окремих категорій населення 3 різних регіонів із популяційною нормою та при проведенні моніторингу ЯЖ різних прошарків населення;

- при порівнянні показників ЯЖ певної групи хворих з популяцйною нормою і проведенні моніторингу ЯЖ різних прошарків населення на протязі необхідного періоду спостереження;

- при комплексній оцінці ефективності реабілітаційних, оздоровчих і соціальних програм у галузі охорони здоров'я для різних категорій населення $[58,59]$

Найбільш поширеними загальними опитувальниками $з$ якості життя є: World Health Oranization's Qualitiof Life - WHOQOL-100 (розроблений спеціалістами ВОO3), SF-36 (Item Short Health Status Survey), «EuroQoL (EQ-5D)», Q-LES-Q та інші, в повних і скорочених версіях [60-62].

Опитувальник «SF-36 Health Status Survey» (SF-36) був розроблений у 1992 р. [67]. Він належить до неспециорічних опитувальників, і дає змогу оцінити всі компоненти якості життя, у тому числі пов'язані зі здоров'ям, і не є специфічними для вікових груп, окремих захворювань або програм лікування.

Опитувальник рекомендований для використання міжнародними домовленностями та стандартами і зараз широко використовується в США, 
країнах Європи і в нашій державі при проведенні досліджень якості життя. Будучи досить коротким, він володіє високою інформативністю, чутливістю та вважається найбільш апробованим і валідним [63-65].

Популярність цього опитувальника полягає в тому, що він дозволяє оцінити HRQOL у хворих із різними нозологіями, порівняно зі здоровими людьми, проводити дослідження у пацієнтів від 14 років і старше, має достатню чутливість для оцінки дослідних показників. Він залишається актуальним, простим, доступним і валідним інструментом для оцінки основних складових фрізичного і психічного здоров'я у пацієнтів [66, 67].

Опитувальник придатний для самостійного заповнення хворим, комп'ютерного опитування, або заповнення лікарем при особистосному контакті 3 хворим або по телефону.

SF-36 складається 311 пунктів, які включають 36 питань, об'єднаних у 8 шкал і 2 інтегральні показники, які дозволяють оцінити: загальний стан здоров'я людини, фрізичне фрункціонування, рольове фрізичне фрункціонування, рольове емоційне фрункціонування, соціальне функціонування, інтенсивність фрізичного болю, життєву активність та психічне здоров'я. Формування шкал дозволяє оцінити два інтегральних показники - фрізичний та психологічний компоненти здоров'я. Результати визначаються в балах (від 0 до 100, де 100 відповідає «повному здоров'ю»), що дозволяє провести їх циоррову та статистичну обробку [68-71].

Опитувальник якості життя В0О3 WHOQOL-100 був розроблений ВООЗ з метою отримання якісного і незалежного інструменту оцінки ЯЖ не залежно від соціального, культурного, демографрічного і політичного контексту.

Опитувальник якості життя BOO3WHOQOL-100 складається зі 100 пунктів, які дозволяють оцінити ЯЖ у 6 сорерах життя людини: фрізичній, психологічній, незалежності, соціальної активності, навколишнього середовища і духовності. Окрім того, 4 питання дають змогу оцінити ЯЖ в цілому.

Його скорочена версія WHOQOL-BREF є більш простою в заповненні й включає в себе 26 питань. 24 питання групуються в 4 шкали, 2 питання (перше і друге) оцінюються ізольовано. Цей опитувальник дозволяє оцінити фрізичне здоров'я, психологічну якість життя, соціальну якість життя та оточення [71, 72].

Опитувальник якості життя Європейської групи EuroQol (EQ-5D) був розроблений об'єднаною групою дослідників із Великобританії, Швеції, Ні- дерландів, Норвегії, Фінляндії. Він є ще одним 3 найпопулярніших опитувальників для визначення якості життя на основі переваг самого пацієнта. Цей опитувальник перекладено 150 мовами і використовується спеціалістами 170 країн. Він є в трьох версіях: 3-level EQ-5D(EQ-5D-3L), 5-level EQ-5D (EQ-5D-5L) и EQ-5D-Youth (EQ-5D-Y). Опитувальник EQ-5D-Y є дитячою версією, яку можуть самостійно заповнювати діти з 8 років. Це багатомірний інструмент оцінки ЯЖ, який може бути виражений одним показником - індексом, тому його називають також індексом здоров'я. Це дає змогу оцінювати стан здоров'я, ефективність лікування, реабілітації, надання різних видів медичної допомоги. Комбінування рівнів по 5 компонентах дозволяє отримати 243 варіанти стану здоров'я, та візуалізувати кількісну оцінку загального статусу здоров'я, використовуючи візуально-аналогову шкалу [73-76].

Спеціальні опитувальники використовуються для оцінки якості життя при окремих нозологічних формах захворювань. Вони створюються спеціально 3 «нуля», або на ґрунті вже відомих широко вживаних опитувальників шляхом їх переробки та адаптації стосовно конкретного захворювання. На даний час відома значна кількість спеціальних опитувальників для таких нозологій, як цукровий діабет, бронхіальна астма, рак, судинна патологія тощо. Однак на даний час їх значна частка знаходиться в стадії розробки та адаптації для різних країн світу.

\section{вИСновки}

Результати проведеного огляду літературних джерел дозволяють зробити висновок, що поняття «якість життя, пов'язана зі здоров'ям» (HRQOL) та його вивчення $€$ новою сучасною методологією охорони здоров'я. Вона дозволяє оцінити результати лікування хворих, реабілітаційні програми та медико-соціальну адаптацію пацієнтів, доповнюючи традиційні методики як на індивідуальному, так і на груповому рівнях. Значний міжнародний досвід вивчення ЯЖ хворих показує його перспективність у всіх розділах медицини.

Найбільш зручними інструментами для оцінки якості життя є опитувальники (загальні та спеціальні), які $€$ універсальними інструментами дослідження, однак вони потребують свого подальшого створення та удосконалення. Для отримання найбільш достовірної і повної інформації необхідно використовувати інструменти 3 високою валідністю, надійністю і чутливістю, відповідно до мети і завданнь дослідження.
ISSN 2706-6282(print) ISSN 2706-6290(online)
Вісник медичних і біологічних досліджень Bulletin of Medical and Biological Research
$1(7), 2021$ 


\section{СПИСОК ЛІТЕРАТУРИ}

1. Новик Т. И. Руководство по исследованию качества жизни в медицине. - 3-е изд., перераб. и дополн. I Т. И. Новик, Т. И. Ионова // РАМН. - М. : Издательство PAEH, 2012. - $528 \mathrm{c}$

2. Новик А. А. Оценка качества жизни больного в медицине / А. А. Новик, С. А. Матвеев, Т.И. Ионова // Клиническая медицина. - 2000. - № 2. - С. 10-13.

3. Рассказова Е. И. Методы диагностики качества жизни в науках о человеке / Е. И. Рассказова // Вестн. Моск. у-та. Сер. 14. Психология. - 2012. - № 3. - С. 95-107.

4. Schalok R. L. The concept of quality of life: what we know and do not know / R. L. Schalok // J. of Intellectual Disability Res. - 2004. - Vol. 48 (3). - P. 203-216. DOI: $10.1111 / j .1365-2788.2003 .00558 . x$

5. Engel G. E. The clinical application of the biopsychosocial model / G. E. Engel // Am. J. Psychiatry. - 1980. - Vol. 137 (5). - P. 535-543. DOI: $10.1176 /$ ajp.137.5.535.

6. Life quality of patients with chronic obstructive pulmonary disease / A. J. McSweeny, I. Grant, R. K. Heaton // Arch. Intern. Med. - 1982. - Vol. 142 (3). - P. 473-478. DOI: $10.1001 /$ archinte.1982.00340160057014

7. Assessment of quality of life in clinical trials of cardiovascular therapies / N. K. Wenger, M. E. Mattson, C. D. Furberg, J. Elinson // Am. J. Cardiol. - 1984. - Vol. 54 (7). - P. 908-913. DOI: 10.1016/s0002-9149(84)80232-5.

8. Малыхин Ф. Т. Качество жизни, обусловленное состоянием здоровья лиц пожилого и старческого возраста : обзор литературы / Ф. Т. Малыхин // Качественная клиническая практика. - 2011. - № 1. - С. 11-18.

9. Basskin L. E. Practical Pharmacoeconomics: How to design, perform and analyze outcomes research / L. E. Basskin // Cleveland: Advanstar Communication, 1998. - $174 \mathrm{p}$

10. Куапдыков Е. К. Качество жизни как один из информативных методов оценки состояния больного : обзор литературы / Е. К. Куапдыков, Ж. С. Абдрахманов // Валеология. - 2010. - № 3. - С. 9-12.

11. Quality of life. Medical Encyclopedia // Chicago: 1995. - 774 p.

12. Johnes P. W. Quality of life measurement the value of standartization / P. W. Johnes // Eur. Resp. Rev. - 1997. Vol. 7 (42). - P. 42-49.

13. Karimi M. Health, health-related quality of life, and quality of life: What is the difference? / M. Karimi, J. Brazier // Pharmacoeconomics. - 2016. - Vol. 34 (7). - P. 645-649. DOI: $10.1007 / \mathrm{s} 40273-016-0389-9$.

14. World Health Organization. The World Health Organization Quality of Life assessment (WHOQOL): position paper from the World Health Organization // Soc. Sci. Med. - 1995. - Vol. 41 (10). - P.1403-1409.

15. Karimi M. Health, health-related quality of life, and quality of life: What is the difference? / M. Karimi, J. Brazier // Pharmaco Economics. - 2016. - Vol. 34. - Issue 7. P. 645-649. DOI: 10.1007/s40273-016-0389-9.

16. Адеева Т. Н. Жизненные траектории взрослых лиц с ограниченными возможностями здоровья : теория и практика исследования / Т. Н. Адеева, И. В. Тихонова, С. А. Хазова // Петербургский психологический журнал. - 2017. - № 4. - C. 25-44.

17. Сурмач М. Ю. Качество жизни, связанное со здоровьем, как предмет изучения социологии медицины / М. Ю. Сурмач // Социология. - 2011. - № 2. - С.100-104.
18. Спиридонов С. П. Индикаторы качества жизни и методологии их фрормирования / С. П. Спиридонов // Вопросы современной науки и практики. - 2010. № 10-12 (31). - С. 208-223.

19. Афранасьева Е. В. Оценка качества жизни, связанного со здоровьем / Е. В. Афранасьева // Качественная клин. практика. - 2010. - № 1. - С. 36-38.

20. Вассерман Л. И. Внутренняя картина болезни в структуре качества жизни у больных с соматической патологией / Л. И. Вассерман, Е. А.Трифонова, В. Л. Федорова // Сибирский психологический журнал. - 2008. № 27. - C. 67-71.

21. Новик А. А. Общий опросник исследования качества жизни 2-го поколения NJQoL-29 / А. А. Новик, Т. И. Ионова, А. В. Киштович // Вестник межнационального центра исследования качества жизни. - 2007. № 9-10. - С. 25-31.

22. Савченко Т. Н. Субъективное качество жизни: подходы, методы оценки, прикладные исследования / Т. Н. Савченко, Г. М. Головина. - М. : Изд-во «Институт психологии РАН», 2006. - 170 с.

23. WHOQOL Croup. Whoch Quality of life? // World Health Forum. - 1996. - Vol. 17 (4). - P. 354-336.

24. Гурылева М. Э. Критерии качества жизни в медицине и кардиологии / М. Э. Гурылева, М.В.Журавлева, Г. Н. Алеева // Русский медицинский журнал. - 2006. Т. 14, № 10. - С. 761-763.

25. Евдокимов В. И. Научно-методологические проблемы оценки качества жизни / В. И. Евдокимов // Вестник психиатрии. - 2008. - № 27. - С. 102-131.

26. Ware J. E. Methods for testing data quality, scaling assumptions and reliability: he IQOLA Project Approach / J. E. Ware, B. Gandek // J. Clin. Epidemiol. - 1998. - Vol. 51 (11). - P. 945-952. DOI: 10.1016/s0895-4356(98)00085-7.

27. Quality of life instruments for economic evaluations in health and social care for older people: A systematic review / P. Makai, W.B.F. Brouwer, M. A. Koopmanschap [et al.] // Soc. Sci Med. - 2014. - Vol. 102. - P. 83-93. DOI: 10.1016/j.socscimed.2013.11.050.

28. Мороз И. Н. Инструменты оценки качества жизни, связанного со здоровьем / И. Н. Мороз // Военная медицина. - 2019. - № 4. - С. 78-85.

29. Евсина О. В. Качество жизни в медицине - важный показатель состояния здоровья пациента : обзор литературы / О. В. Евсина // Электронный научный журнал «Личность в меняющемся мире: здоровье, адаптация, развитие». - 2013. - № 1. - С. 119-133.

30. Basic issues concerning health-related quality of life / R. Sosnowski, M. Kulpa, U. Ziętalewicz [et al.] // Cent. European J. Urol. - 2017. - No. 70. - P. 206-211. DOI: $10.5173 /$ ceju.2017.923

31. PROQOLID, the patient-reported outcome and quality of life [Electronic resource]. - 2001-2014. -Access mode : http://www.proqolid.org.

32. Золоев Г. К. Исследование качества жизни в клинической практике / Г. К. Золоев, Е. М. Васильченко // Медицина в Кузбассе. - 2004. - № 1. - С. 41-44.

33. Summarizing health-related quality of life (HRQOL): development and testing of a one-factor model / S. Yin, R. Njai, L. Barker [et al.] // Population Health Metrics. 2016. - Vol. 14 (22). - P. 22-30. DOI: 10.1186/s12963-0160091-3. 
34. Новик А. А. Руководство по исследованию качества жизни в медицине / А. А. Новик, Т. И. Ионова. - СПб. : Нева ; М. : ОЛМА-ПРЕСС Звездный мир, 2002. - 320 с.

35. Eurohis: Разработка общего инструментария для опроса о состоянии здоровья. - М.: Права человека, 2005. - 193 c.

36. Mihaila V. General population norms for Romania using the short form 36 health survey (SF-36) / V. Mihaila, D. Enachescu, C. Davila // QL News Letter. - 2001. N 26. - P. 17-18.

37. Макарова У. И. Метология расчета QALY в фармакоэкономическом моделировании: использование опросников изучения качества жизни пациента / У. И. Макарова, Р. И. Ягудина // Фармакоэкономика, теория и практика. - 2018. - Т. 6, № 1. - C. 7-12. DOI: https:// doi.org/10.30809/phe.1.2018.1

38. Ilic I. Assessment quality of life: current approaches / I. Ilic, I. Milic, M. Arandelovic // Acta Medica Medianae. 2010. - Vol. 49 (4). - P. 52-60.

39. The quality of life (QOL) research movement: Past, present and future / M. J. Sirgy, A. C. Michalos, A. L. Ferris [et al.] // Social Indicators Res. - 2006. - Vol. 76 (3). P. 343-466. DOI: 10.1007 / s11205-005-2877-8.

40. Власов В. В. Эфрфективность диагностических исследований / В. В. Власов. - М. : Медицина, 2001. - 246 с.

41. Звягина Н. М. Качество жизни как критерий оценки эффрективности лечебных и реабилитационных программ / Н. М. Звягина, С. С. Кудренко, О. В. Антонов //Journal of Siberian Medical Sciences. - 2015. - № 6. - C. 30-36.

42. Jenkinson C. Short form 36 (SF-36) health survey questionnaire: normative data for adults of working age / C. Jenkinson, A. Coulter, L. Wright//BMJ. -1993. - Vol. 306 (6890). - P. 1437-1440. DOI: 10.1136 / bmj.306.6890.1437.

43. Cella, D. F. Quality of Life: concepts and definition / D. F. Cella / J. Pain Symptom Manage. -1994. - Vol. 9 (3). - P. 186-192. DOI: 10.1016/0885-3924(94)90129-5.

44. Eurohis: Разработка общего инструментария для опроса о состоянии здоровья. - М.: Права человека, 2005. - $193 \mathrm{c}$.

45. Готье С. В. Методы оценки качества жизни прижизненных доноров органов / С. В. Готье, В. К. Константинов // Вестник трансплантологии и искусственных органов. - 2017. - T. 19, № 1. - C. 82-88. DOI: 10.15825/1995-1191-2017-1-82-88

46. Donor quality of life after living donor liver transplantation / M. B. Parolin, C. T. Lazzaretti, J. H. Lima [et al.] // Transplant. Proc. - 2004. - Vol. 36, No. 4. P. 912-913. DOI: 10.1016/j.transproceed.

47. Евсина О. В. Качество жизни в медицине важный показатель состояния здоровья пациента / О. В. Евсина // Личность в меняющемся мире: здоровье, адаптация, развитие. - 2013. - №1. - С. 119-133.

48. Жолдасбекова А. С. Современные подходы к изучению качества жизни в медицине и кардиологии : литературный обзор / А. С. Жолдасбекова, Ж. А. Калматаева // Вестник КазНМУ. - 2016. - № 3. - С. 1-6.

49. Effectiveness of a web-based application to monitor health-related quality of life / L. Haverman, M. A. J. van Rossum, van M. Veenendaal [et al.] // Pediatrics. - 2013. Vol. 131 (2). P. e533-e543. DOI:10.1542/peds.2012-0958.

50. Ferreira L. N. Comparing the performance of the SF-6D and the EQ-5D in different patient groups / L. N. Ferreira, P. L. Ferreira, L. N. Pereira // Acta Med.
Port. - 2014. - Vol. 27 (2). - P. 236-245. DOI: 10.20344/ amp.4057.

51. EQ-5D [Элетронный ресурс]. Режим доступа: https://euroqol.org/ - дата обращения - 20.01.2021.

52. Assessment of quality of life [Элетронный ресурс]. Режим доступа: http://aqol.com.au/ - дата обращения 20.01.2021.

53. Комелягина Е.Ю. Русскоязычная версия опросника для оценки качества жизни больных с периферической полинейропатией: валидация и перспективы применения / Е. Ю. Комелягина, М. Б. Анциферов, О. М. Уварова // Сахарный диабет. - 2014. - 17(2). C. 56-65. DOI: 10.14341/DM2014256-65.

54. Measuring and valuing health. The University of Sheffield [Элетронный ресурс]. Режим доступа: https:// ugc. futurelearn.com/uploads/files/58/b4/58b44004-14ce45eb-886c-db5fa958ae5/Measuring_and_Valuing_Health_ Useful_Terminology.pdf

55. Health-related quality of life of the general German population in 2015: Results from the EQ-5D-5L / M. B. Huber, J. Felix, M. Vogelmann, R. Leidl // Int. J. Environ. Res. Public Health. - 2017. - Vol. 14 (4). - P. 426-437. DOI: 10.3390/ ijerph14040426.

56. Golicki D. EQ-5D-5L Polish population norms / D. Golicki, M. Niewada // Arch. Med. Sci. - 2017. - Vol. 13 (1). - P. 191-200. DOI: 10.5114/aoms.2015.52126.

57. Common patterns of morbidity and multi-morbidity and their impact on health-related quality of life: evidence from a national survey / R. E. Mujica-Mota, M. Roberts, G. Abel [et al.] // Qual Life Res. - 2015. - Vol. 24. - P. 909918. DOI: $10.1007 / \mathrm{s} 11136-014-0820-7$.

58. Сухонос Ю. А. Особенности популяционного исследования качества жизни : автореф. дисс. на соискание уч. степени канд. мед. наук / Ю. А. Сухонос. - СПб., 2003. - № 13 [Электронный ресурс]. - URL: http://www/dissercat. com/content/osobennosti-populyatsionnogo-issledovaniyakachestva-zhizni (дата обращения: 19.01.2021).

59. Baker F. Quality of life in the evaluation of community support systems / F. Baker, J. Intagliata // Evaluat. Progr. Plann. - 1982. - Vol. 5 (1). - P. 69-79. DOI: 10.1016/01497189(82)90059-3.

60. Skevinkton S. M. Changes in quality of life of patients receiving antidepressant medication in primary care: validation of the WHOQOL-100 / S. M. Skevinkton, A. Wright // The British J. of Psychiatry. - 2001. - Vol. 178. - P. 261-267.

61. SF-36 Health survey. Health assessments lab, medical outcomes trust and quality metric incorporated.- 2006.

62. Шипова Н. С. Применение методики «Краткий опросник ВОЗ для оценки качества жизни» в исследовании лиц с ограниченніми возможностями здоровя / Н. С. Шипова // Вестник КГУ. - 2018. - № 4. - С. 250- 255.

63. Ware J. E. The MOS 36-item short form health survey: Conceptual framework and item selection / J. E. Ware, C. D. Sherbour // Medical Care. - 1992. - Vol. 30 (6). P. 473-483.

64. Campolina A. G. SF-36 and the development of new assessment tools for quality of life / A. G. Campolina R. M. Ciconelli // Acta Reumatol. Port. - 2008. - Vol. 33 (2). - P. 127-133.

65. Использование опросника SF-36 в оценке качества жизни у пациентов с хронической тромбоэмболической легочной гипертензией / Н. А. Шо- 
стак, А. А. Клименко, В. С. Шеменкова, А. В. Свет // Клиницист. - 2017. - Т. 11, № 3-4. - С. 44-49. DOI: 10.17650/1818-8338-2017-11-3-4-44-49

66. Ware J. E. Measuring patients' views: the optimum outcome measure. SF 36: a valid, reliable assessment of health from the patient's point of view / J. E. Ware // BMJ. - 1993. - Vol. 306 (6890). - P. 1429-1430. DOI:10.1136/ bmj.306.6890.1429.

67. Lins L. SF-36 total score as a single measure of health-related quality of life: Scoping review / L. Lins, F. M. Carvalho // SAGE Open Medicine. - 2016. - Vol. 4. P. 1-12. DOI: $10.1177 / 2050312116671725$.

68. Популяционные показатели качества жизни по опроснику SF-36 (результаты многоцентрового исследования качества жизни «МИРАЖ») / В. Н. Амирджанова, Д. В. Горячев, Н. И. Коршунов [и др.] // Научно-практическая ревматология. - 2008. - Т. 46, № 1. - С. 36-48. DOI: 10.14412/1995-4484-2008-852.

69. Pelle A. J. What is the use? Application of the short form (SF) questionnaires for the evaluation of treatment effects / A. J. Pelle, N. Kupper, F. Mols, P. de Jonge // Qual. Life Res. - 2013. - Vol. 22 (6). - P. 1225-1230. DOI: 10.1007/s11136-012-0266-8.

70. Инструкция по обработке данных, полученных с помощью опросника SF-36. URL: http://bono-esse.ru/ blizzard/RPP/sf36.pdf. [Instructions for processing data obtained with the SF-36 questionnaire. URL access mode: http://bono-esse.ru/blizzard/RPP/sf36.pdf. (In Russ.)]

\section{REFERENCES}

1. Novik TI, Ionova TI. Guidelines for the Study of Quality of Life in Medicine. [Руководство по исследованию качества жизни в медицине] Moscow: RAMS; 2012. Russian.

2. Novik AA, Matveev SA, Ionova TI. [Assessment of the patient's quality of life in medicine]. Klinicheskaya meditsina. 2000;2: 10-3. Russian.

3. Rasskazova Yel. [Methods for diagnosing the quality of life in the human sciences]. Vestn. Mosk. Ue-ta. Ser.14. Psikhologiya. 2012;3: 95-07. Russian.

4. Schalok RL. The concept of quality of life: what we know and do not know. J. of Intellectual Disability Res. 2004;48(3): 203-16. Available from: http://dx.doi.org/10.1111/ j.1365-2788.2003.00558.x [Accessed March 2004].

5. Engel GE. The clinical application of the biopsychosocial model. Am. J.Psychiatry. 1980;137(5): 53543. Available from: http://dx.doi.org/ 10.1176 / ajp.137.5.535 [Accessed May 1980]

6. McSweeny AJ, Grant I, Heaton RK, Adams KM, Timms RM. Life quality of patients with chronic obstructive pulmonary disease. Arch Intern Med. 1982;142(3): 473-8. Available from: http://dx.doi.org/10.1001/ archinte.1982.00340160057014 [Accessed March 1982]

7. Wenger NK, Mattson ME, Furberg CD, Elinson J. Assessment of quality of life in clinical trials of cardiovascular therapies. Am. J.Cardiol. 1984;54(7): 908-13. Available from: http://dx.doi.org/10.1016/s0002-9149(84)80232-5 [Accessed July 1984]

8. Malykhin FT. [Quality of life due to the state of health of elderly and senile persons]. Kachestvennaya klinicheskaya praktika. 2011;1: 11-8. Russian.

9. Basskin LE. Practical Pharmacoeconomics: How to
71. Skevington S. M. The World Health Organization's WHOQOL-BREF quality of life assessment: Psychometric properties and results of the international field trial A Report from the WHOQOL Group / S. M. Skevington, M. Lotfy, K. A. O'Connell // Quality of Life Res. - 2004. - Vol. 13 (2). P. 299-310. DOI: 10.1023/B:QURE.0000018486.91360.00.

72. Использование опросника качества жизни (версия ВО3) в психиатрической практике : пособ. для врачей и психологов / Г. В. Бурковский, М. М. Кабанов, А. П. Коцюбинский [и др.]. - СПб., 1998. - 98 с.

73. Ferreira L. N. Comparing the performance of the SF$6 D$ and the EQ-5D in different patient groups / L. N. Ferreira, P. L. Ferreira, L. N. Pereira // Acta Med. Port. - 2014. Vol. 27 (2). - P. 236-245. DOI: 10.20344/amp.4057.79.

74. EQ-5D [Элетронный ресурс]. Режим доступа: https://euroqol.org/ - дата обращения - 03.01.2021.

75. Хабибуллина А. Р. Методология оценки качества жизни связанного со здоровьем с использованием опросника EQ-5D-3L / А. Р. Хабибуллина, Е. А. Александрова // Российский медицинский журнал. - 2019. T. 25, № 4. - C. 202-209. DOI: 10.18821/0869-2106-201925-4-202-209.

76. Амирджанова В. Н. Валидация русской версии общего опросника EuroQol-5D (EQ-5D) / В. Н. Амирджанова, Ш. Ф. Эрдес // Научно-практическая ревматология. - 2007. - T. 45, № 3. - C. 69-76. DOI: 10.14412/19954484-2007-691.

design, perform and analyze outcomes research. Cleveland: Advanstar Communication; 1998.

10. Kuapdykov YeK, Abdrakhmanov ZhS. [Quality of life as one of the informative methods for assessing the patient's condition]. Valeologiya. 2010;3: 9-12. Russian

11. Quality of life. Medical Encyclopedia. Shicago;1995.774 p.

12. Johnes PW. Quality of life measurement the value of standartization. Eur Resp Rev. 1997;7(42): 42-9.

13. Karimi M, Brazier J, Health, health-related quality of life, and quality of life: What is the difference? Pharmacoeconomics. 2016;34(7): 645-9. Available from: http://dx.doi.org/ 10.1007/ s40273-016-0389-9 [Accessed July 2016].

14. World Health Organization. The World Health Organization Quality of Life assessment (WHOQOL): position paper from the World Health Organization. Soc Sci Med. 1995;41(10): 1403-9.

15. Karimi M, Brazier J. Health, Health-related quality of life, and quality of life: What is the difference? Pharmaco Economics. 2016;34(7): 645-9. Available from: http://dx.doi. org/ 10.1007/s40273-016-0389-9 [Accessed July 2016].

16. Adeeva TN, Tikhonova IV, Khazova SA. [Life trajectories of adults with disabilities: theory and practice of research]. Peterburgskiy psikhologicheskiy zhurnal. 2017;4: 25-44. Russian

17. Surmach MYu. [Health-related quality of life as a subject of study in the sociology of medicine]. Sotsiologiya. 2011;2: 100-4. Russian.

18. Spiridonov SP. [Life quality indicators and methodologies for their formation]. Voprosy sovremennoy nauki i praktiki. 2010;10-12 (31): 208-23. Russian 
19. Afanaseva YeV. [Assessment of health-related quality of life]. Kachestvennaya klin. praktika. 2010;1: 36-8. Russian.

20. Vasserman LI, Trifonova YeA, Fedorova VL. [Internal picture of the disease in the structure of the quality of life in patients with somatic pathology]. Sibirskiy psikhologicheskiy zhurnal. 2008;27: 67-71. Russian.

21. Novik AA, Ionova TI, Kishtovich AV. [General questionnaire of the study of the quality of life of the 2nd generation NJQoL-29]. Vestnik mezhnatsionalnogo tsentra issledovaniya kachestva zhizni. 2007;9-10: 25-31. Russian.

22. Savchenko TN, Golovina GM. Subjective quality of life: approaches, assessment methods, applied research. [Субъективное качество жизни: подходы, методы оценки, прикладные исследования]. Moscow: Publishing house "Institute of Psychology RAS"; 2006. Russian.

23. WHOQOL Croup. Whoch Quality of life? World Health Forum. 1996;17(4): 354-6.

24. Guryleva ME, Zhuravleva MV, Aleeva GN. [Quality of life criteria in medicine and cardiology]. Russkiy meditsinskiy zhurnal. 2006;10: 761-3. Russian

25. Yevdokimov VI. [Scientific and methodological problems of assessing the quality of life]. Vestnik psikhiatrii. 2008;27: 102-31. Russian.

26. Ware JE, Gandek B. Methods for testing data quality, scaling assumptions and reliability: he IQOLA Project Approach. J. Clin. Epidemiol. 1998;51(11): 94552. Available from: http://dx.doi.org/ 10.1016/s08954356(98)00085-7 [Accessed November 1998].

27. MakaiP, BrouwerWBF, KoopmanschapMA, StolkEA, Nieboer AP. Quality of life instruments for economic evaluations in health and social care for older people: A systematic review.Soc. Sci Med. 2014;102: 83-93. Available from: http://dx.doi.org/ 10.1016/j.socscimed.2013.11.050 [Accessed 2014].

28. Moroz IN. [Health-related quality of life assessment tools]. Voennaya meditsina. 2019;4: 78-85. Russian.

29. Yevsina OV. [Quality of life in medicine is an important indicator of a patient's health]. Elektronnyy nauchnyy zhurnal «Lichnost $v$ menyayushchemsya mire: zdorove, adaptatsiya, razvitie». 2013;1: 119-33. Russian.

30. Sosnowski R, Kulpa M, Ziętalewicz U, Wolski1 JK, Nowakowski R, Bakuła R, et al. Basic issues concerning health-related quality of life. Cent European J Urol. 2017;70: 206-11. Available from: http://dx.doi.org/ 10.5173/ ceju.2017.923 [Accessed 2017].

31. PROQOLID, the Patient-Reported Outcome and Quality Of Life [Electronic resource]. 2001-2014. Available from: http://www.proqolid.org.

32. Zoloev GK, Vasilchenko YeM. [Research on quality of life in clinical practice]. Meditsina v Kuzbasse. 2004;1: 41-4. Russian.

33. Yin $S$, Njai $R$, Barker L, Siegel PZ, Liao $Y$. Summarizing health-related quality of life (HRQOL): development and testing of a one-factor model. Population Health Metrics. 2016;14 (22): 22-30. Available from: http:// dx.doi.org/ 10.1186/s12963-016-0091-3 [Accessed 2016].

34. Novik AA, Ionova TI. Guidelines for the Study of Quality of Life in Medicine. [Руководство по исследованию качества жизни в медицине] Saint Petersburg: Neva. OLMA-PRESS Star World; 2002. Russian.

35. Eurohis. Development of a generic health survey toolkit. [Разработка общего инструментария для опро- са о состоянии здоровья] Moscow: Human rights; 2005. Russian.

36. Mihaila V, Enachescu D, Davila C. General Population Norms for Romania using the Short Form 36 Health Survey (SF-36). QL News Letter. 2001; 26:17-8.

37. Makarova UI, Yagudina RI. [Metology for calculating QALY in pharmacoeconomic modeling: using questionnaires for studying the patient's quality of life]. Farmakoekonomika, teoriya i praktika. 2018;1(6): 7-12. Russian. Available from: http://dx.doi.org/ 10.30809/phe.1.2018.1 [Accessed 2018].

38. Ilic I, Milic I, Arandelovic M. Assessment quality of life: current approaches. Acta Medica Medianae. 2010;49(4): 52-60.

39. SirgyMJ, MichalosAC, FerrisAL, RichardA, EasterlinRA, Patrick D, et al. The quality of life (QOL) research movement: Past, present and future. Social Indicators Res. 2006;76 (3): 343-466. Available from: http://dx.doi.org/10.1007 / s11205005-2877-8 [Accessed March 2006].

40. Vlasov VV. The effectiveness of diagnostic tests. [Эффективность диагностических исследований] Moscow: Medicine; 2001. Russian.

41. Zvyagina NM, Kudrenko SS, Antonov OV. [Quality of life as a criterion for assessing the effectiveness of treatment and rehabilitation programs]. Journal of Siberian Medical Sciences. 2015;6: 30-6. Russian.

42. Jenkinson C, Coulter A, Wright L. Short form 36 (SF36) health survey questionnaire: normative data for adults of working age. BMJ.1993;306(6890): 1437-40. Available from: http://dx.doi.org/10.1136 / bmj.306.6890.1437 [Accessed 1993].

43. Cella DF. Quality of Life: concepts and definition. J. Pain Symptom Manage.1994; 9 (3):186-92. Available from: http://dx.doi.org/10.1016/0885-3924(94)90129-5 [Accessed March 1994].

44. Eurohis: Development of a common toolkit for a health survey. [Разработка общего инструментария для опроса о состоянии здоровья] Moscow: Human rights; 2005. Russian.

45. Gote SV, Konstantinov VK. [Methods for assessing the quality of life of living organ donors]. Vestnik transplantologii i iskusstvennykh organov. 2017;1:82-8. Russian. Available from: http://dx.doi.org/ 10.15825/19951191-2017-1-82-88 [Accessed 2017].

46. Parolin MB, Lazzaretti CT, Lima JH, Freitas AC, Matias JE, Coelho JC. Donor quality of life after living donor liver transplantation. Transplant. Proc.2004;4(36): 912-13. Available from: http://dx.doi.org/10.1016/j.transproceed [Accessed May 2004].

47. Yevsina OV. [Quality of life in medicine is an important indicator of a patient's health status]. Lichnost $v$ menyayushchemsya mire: zdorove, adaptatsiya, razvitie. 2013;1: 119-33. Russian.

48. Zholdasbekova AS, Kalmataeva ZhA. [Modern approaches to the study of the quality of life in medicine and cardiology]. Vestnik KazNMU. 2016;3: 1-6. Russian.

49. Haverman L, van Rossum MAJ, van Veenendaal M, van den Berg M, Dolman KM, Swart J, et al. Effectiveness of a Web-Based Application to Monitor Health-Related Quality of Life. Pediatrics. 2013;131(2): e533-e43. Available from: http://dx.doi.org/10.1542/peds.2012-0958 [Accessed February 2013].

50. Ferreira LN, Ferreira PL, Pereira LN. Comparing the performance of the SF-6D and the EQ-5D in different patient 
groups. Acta Med. Port. 2014;27(2): 236-45. Available from: http://dx.doi.org/ 10.20344/amp.4057 [Accessed February 2014].

51. EQ-5D. Electronic resource [Электронный ресурс]. Available from: https://euroqol.org/ [Accessed 20.01.2021].

52. Assessment of quality of life. Electronic resource [Элетронный ресурс]. Available from: http://aqol.com.au/ [Accessed 20.01.2021].

53. Komelyagina YeYu, Antsiferov MB, Uvarova OM. [Russian-language version of the questionnaire for assessing the quality of life of patients with peripheral polyneuropathy: validation and application prospects]. Sakharnyy diabet. 2014;17(2): 56-65. Russian. Available from: http://dx.doi.org/10.14341/DM2014256-65 [Accessed February 2017].

54. Measuring and valuing health. The University Of Sheffield. Electronic resource [Элетронный ресурс]. Available from:

https://ugc.futurelearn.com/uploads/files/58/ b4/58b44004-14ce-45eb-886c-db5fa958ae5/Measuring_ and_Valuing_Health_Useful_Terminology.pdf.

55. Huber MB, Felix J, Vogelmann M, Leidl R. HealthRelated Quality of Life of the General German Population in 2015: Results from the EQ-5D-5L. Int J Environ Res Public Health. 2017;14(4): 426-37. Available from: http://dx.doi. org/10.3390/ijerph14040426 [Accessed April 2017].

56. Golicki D, Niewada M. EQ-5D-5L Polish population norms. Arch Med Sci. 2017;13(1): 191-200. Available from: http://dx.doi.org/10.5114/aoms.2015.52126 [Accessed January 2017].

57. Mujica-Mota RE, Roberts M, Abel G, Elliott M, Lyratzopoulos $\mathrm{G}$, Roland $\mathrm{M}$, et al. Common patterns of morbidity and multi-morbidity and their impact on healthrelated quality of life: evidence from a national survey. Qual Life Res. 2015;24: 909-18. Available from: http://dx.doi.org/ 10.1007/s11136-014-0820-7 [Accessed 2015].

58. Sukhonos YuA. Features of the population study of the quality of life. [Особенности популяционного исследования качества жизни]. Saint Petersburg.2003;13 Available from: http://www/dissercat.com/content/osobennosti-populyatsionnogo-issledovaniya-kachestva-zhizni. [Accessed 19.01.2021]

59. Baker $F$, Intagliata J. Quality of life in the evaluation of community support systems. Evaluat Progr Plann. 1982;5(1): 69-79. Available from: http://dx.doi.org/ 10.1016/0149-7189(82)90059-3 [Accessed January 1982].

60. Skevinkton SM, Wright A. Changes in quality of life of patients receiving antidepressant medication in primary care: validation of the WHOQOL-100. The British J. of Psychiatry. 2001;178: 261-7.

61. SF-36 Health survey. Health assessments lab, medical outcomes trust and quality metric incorporated. 2006.

62. Shipova NS. [Application of the methodology "Brief WHO questionnaire for assessing the quality of life" in the study of persons with disabilities] Vestnik KGU.2018;4: 2505. Russian

63. Ware JE, Sherbour CD. The MOS 36-item short form health survey: Conceptual framework and item selection. Medical Care. 1992;30(6): 473-83.

64. Campolina AG, Ciconelli RM. SF-36 and the development of new assessment tools for quality of life. Acta Reumatol Port. 2008;33(2): 127-33.
65. Shostak NA, KlimenkoAA, Shemenkova VS, SvetAV. [The use of the SF-36 questionnaire in assessing the quality of life in patients with chronic thromboembolic pulmonary hypertension]. Klinitsist. 2017; 3-4(11): 44-9. Available from: http://dx.doi.org/ 10.17650/1818-8338-2017-11-3-4-44-49 [Accessed November 2017]. Russian.

66. Ware JE. Measuring patients' views: the optimum outcome measure. SF 36: a valid, reliable assessment of health from the patient's point of view. BMJ.1993; 306 (6890): 1429-30. Available from: http://dx.doi.org/ 10.1136/ bmj.306.6890.1429 [Accessed 1993].

67. Lins L, Carvalho FM. SF-36 total score as a single measure of health-related quality of life: Scoping review. SAGE Open Medicine. 2016;4: 1-12. Available from: http:// dx.doi.org/ 10.1177/2050312116671725 [Accessed 2016].

68. Amirdzhanova VN, Goryachev DV, Korshunov NI, Rebrov AP, Sorotskaya VN. [Population indicators of quality of life according to the SF-36 questionnaire]. Nauchnoprakticheskaya revmatologiya. 2008;1(46): 36-48. Available from: http://dx.doi.org/ 10.14412/1995-4484-2008-852 [Accessed 2008]. Russian.

69. Pelle AJ, Kupper N, Mols F, de Jonge P. What is the use? Application of the short form (SF) questionnaires for the evaluation of treatment effects. Qual Life Res. 2013;22(6): 1225-30. Available from: http://dx.doi.org/ 10.1007/s11136012-0266-8 [Accessed June 2013].

70. Instructions for processing data obtained using the SF-36 questionnaire. [Инструкция по обработке данных, полученных с помощью опросника SF-36]. Available from: http://bono-esse.ru/blizzard/RPP/sf36.pdf. Russian.

71. Skevington SM, Lotfy M, O'Connell KA. The World Health Organization's WHOQOL-BREF quality of life assessment: Psychometric properties and results of the international field trial A Report from the WHOQOL Group. Quality of Life Res. 2004;13(2): 299-310. Available from: http://dx.doi.org/ 10.1023/B:QURE.0000018486.91360.00 [Accessed February 2004].

72. Burkovskiy GV, Kabanov MM, Kotsyubinskiy AP, Levchenko YeV, Lomachenkov AS. The use of the quality of life questionnaire (WHO version) in psychiatric practice: A guide for doctors and psychologists. [Использование опросника качества жизни (версия ВО3) в психиатрической практике: Пособие для врачей и психологов] Saint Petersburg; 1998. Russian.

73. Ferreira LN, Ferreira PL, Pereira LN. Comparing the performance of the SF-6D and the EQ-5D in different patient groups. Acta Med. Port. 2014; 27(2): 236-45. Available from: http://dx.doi.org/ 10.20344/amp.4057.79 [Accessed February 2014].

74. EQ-5D [Electronic resource]. Available from: https:// euroqol.org/ [Accessed 03.01.2021]

75. Khabibullina AR, Aleksandrova YeA. [Methodology for assessing health-related quality of life using the EQ-5D-3L questionnaire]. Rossiyskiy meditsinskiy zhurnal. 2019;4(25): 202-9. Available from: http://dx.doi.org/ 10.18821/0869-21062019-25-4-202-209 [Accessed 2019]. Russian.

76. Amirdzhanova VN, Erdes ShF. [Validation of the Russian version of the general questionnaire EuroQol-5D (EQ5D)]. Nauchno-prakticheskaya revmatologiya. 2007;3(45): 69-76. Available from: http://dx.doi.org/10.14412/1995-44842007-691 [Accessed 2007]. Russian. 